\title{
Alfalfa (Medicago sativa L.) overseeding on mature switchgrass (Panicum virgatum L.) stand: biomass yield and nutritive value after the establishment year
}

\author{
Alberto Mantino, Giorgio Ragaglini, Nicoletta Nassi o di Nasso, Cristiano Tozzini, \\ Fabio Taccini, Enrico Bonari \\ Institute of Life Sciences, Scuola Superiore Sant'Anna, Pisa, Italy
}

\begin{abstract}
Perennial crops can positively act on the environment providing a better inter-annual protection of soil cover from water erosion, limiting soil fertility degradation, the risk of nutrient leaching and the exploitation of water for irrigation. Switchgrass (Panicum virgatum L.), a warm-season grass native from North America, has been cultivated for decades as forage crop and only recently as bioenergy crop. Even if several studies reported a positive effect of nitrogen $(\mathrm{N})$ supply on switchgrass yield and quality, potential indirect and direct environmental risks (e.g., eutrophication and greenhouse gas emission) are related to this practice. For this reason grass-legume intercropping can represent a sustainable practice able to increase biomass yield and quality, and at the same time to improve $\mathrm{N}$ use efficiency, soil structure and fertility. Based on this, the aim of this study was to evaluate the suitability of switchgrass to Mediterranean environment as forage crop and to improve biomass yield and its nutritional value by intercropping with alfalfa (Medicago sativa L). During spring 2013, in two switchgrass pure stands (varieties Alamo and Blackwell, respectively), alfalfa was established through direct seeding implementing a split-plot experimental design. Our first year results report a positive effect of the intercropping in increasing the total annual yield of the stand, of about $20 \%$ with respect to the pure switchgrass stand. However, the presence of alfalfa negatively affected switchgrass yield in the mixture. In both varieties, the crude protein
\end{abstract}

Correspondence: Alberto Mantino, Institute of Life Sciences, Scuola Superiore Sant'Anna, p.zza Martiri della Libertà 33, 56127 Pisa, Italy.

E-mail: alberto.mantino@sssup.it

Key words: Alfalfa; forage; intercropping; over-seeding; switchgrass.

Conflict of interest: the authors declare no potential conflict of interest.

Conference presentation: SIA XLIV Congress, Bologna, 2015.

Received for publication: 20 January 2016.

Revision received: 12 April 2016.

Accepted for publication: 16 April 2016

(c) Copyright A. Mantino et al., 2016

Licensee PAGEPress, Italy

Italian Journal of Agronomy 2016; 11:747

doi:10.4081/ija.2016.747

This article is distributed under the terms of the Creative Commons Attribution Noncommercial License (by-nc 4.0) which permits any noncommercial use, distribution, and reproduction in any medium, provided the original author(s) and source are credited. content was higher in the mixture than in the pure switchgrass stands. Conversely, the neutral detergent fibre content in the mixture was lower than in pure switchgrass. Then, our results show that switchgrass-alfalfa intercropping leads to increase the profitability of grassland-based livestock production.

\section{Introduction}

Forage cropping systems need to reduce greenhouse gas (GHG) emissions, in order to balance the increase of global demand of meat, milk and dairy products. The carbon footprint of animal products (Pulina et al., 2011; Havlik et al., 2014) is also to be reduced. Moreover, in Europe, the import of soybean for animal feeding, as protein supply in intensive systems, is associated with increased carbon emissions generated by land-use change in South America from forest to cropland (Weightman et al., 2011). Soussana et al. (2010) indicated the production of low-input grassland-based feedstock as sustainable way for reducing GHG emissions associated to animal products. In fact, perennial species demonstrated to have a high potential in storing carbon into soil. Moreover, perennial crops may have also an indirect mitigation effect on global warming, as they require less herbicides, fertilisers and tillage operations than annual crops (Glover et al., 2010, 2012). Perennial crops can positively act on the environment also on a local scale, providing the soil with an all-year-long protection from water erosion thus limiting the soil fertility degradation, the risk of nutrient leaching and the exploitation of water for irrigation (Durán Zuazo and Rodríguez Pleguezuelo, 2008; Morgan et al., 2010; Glover et al., 2012; Vallebona et al., 2016).

Among perennial crops, switchgrass (Panicum virgatum L.), a warm-season grass native from North America, has been cultivated for decades as forage crop and only recently as bioenergy crop. In North America, Burns et al. (2011) showed the possibility of switchgrass grazing by steers and underlined the key role of stocking rates in summer dry period on switchgrass grassland for: i) ensuring an adequate pasture availability; ii) allowing a long-lasting of the sward. However, for the fresh consumption of switchgrass by ruminants, it is important to detect and assess the occurrence of anti-nutritional compounds like saponins (Lee et al., 2009; Cheok et al., 2014). Recently, switchgrass was studied also for a dual-purpose production, as forage and bioenergy crop, harvesting the herbage more often than once per year. In fact a double harvesting system could allow the valorisation of the early-cut biomass with high-nutritive value for animal feeding, while the lowquality regrowth biomass would be set for energy uses (Guretzky et al., 2010; Rogers et al., 2012; Mosali et al., 2013; Rogers et al., 2014; Sulc and Franzluebbers, 2014).

In Europe, so far, switchgrass has been studied mainly as bioenergy crop. In particular some authors highlighted its suitability to the 
Mediterranean environment with yield from 5 to $20 \mathrm{Mg}$ dry matter (DM) $\mathrm{ha}^{-1} \mathrm{yr}^{-1}$ (Alexopoulou et al., 2008; Nassi o di Nasso et al., 2015). In particular, during the Mediterranean warm season, grasses have the potential to stabilise forage production, as hay or pasture, thus enhancing the production during the dry season (Gherbin et al., 2007). Moreover, in this area, Monti et al. (2012) observed a marked GHG emission reduction by the conversion from cropland to switchgrass grassland. For all this reasons, the introduction of switchgrass in the Mediterranean rainfed cropping systems could represent an opportunity to set up a sustainable feedstock production.

Several authors reported a positive response of switchgrass yields to increasing nitrogen (N) fertilisation levels (Gurezky et al., 2010; Nassi o Di Nasso et al., 2015). Nevertheless, nitrogen distribution associated to grass cultivation may increase the risk of eutrophication and directly and indirectly cause GHG emissions (Anglade et al., 2015). To cope with this problem, the use of a legume as intercropping species appears to be an environmental friendly option to increase $\mathrm{N}$ use efficiency. Grass-legume intercropping is an agro-ecological practice that can enhance biomass yields, increase feedstock quality and $\mathrm{N}$ use efficiency, while improving soil structure and fertility (Wezel et al., 2014). Ashworth et al. (2015), in life-cycle assessment (LCA) evaluation at the landscape level, highlighted that the environmental sustainability of switchgrass cropping is ensured by a low $\mathrm{N}$ fertilisation level $(<67 \mathrm{~kg}$ $\mathrm{ha}^{-1} \mathrm{~N}$ fertiliser) or by a legume intercropping. Legume-grass mixtures have a higher nutritional value than pure-grass forage. In fact legumes enhance the digestibility and the protein content of forage and also, their occurrence in the pasture increases the voluntary intake of grazing animals (Luscher et al., 2014).

With these premises, the aim of this study was to evaluate the suitability of switchgrass to Mediterranean environment as forage crop and to improve biomass yield and its nutritive value by intercropping with a legume. Specifically, the responses to multiple harvests $(\mathrm{H})$ of two switchgrass varieties, as pure crop and in a mixture with alfalfa (Medicago sativa L.), were evaluated under rainfed conditions in a lowinput cropping system.

\section{Materials and methods}

The study was conducted in 2014 at the Agro-Environmental Research Centre Enrico Avanzi of the University of Pisa, located in San Piero a Grado (Pisa) (43.667205 N, 10.313160 E), in a soil characterised by clay-loam texture, alkaline $\mathrm{pH}(8.1)$ and $18 \mathrm{mg} \mathrm{g}^{-1}$ of organic matter. During spring 2009 two side-by-side pure switchgrass cultivars, Alamo and Blackwell, were established through direct seeding (300 seeds $\mathrm{m}^{-2}$ ). From 2010 to 2013 switchgrass was harvested once per year in winter, yielding an average of 20 and $15 \mathrm{Mg} \mathrm{DM} \mathrm{ha}^{-1} \mathrm{yr}^{-1}$ for Alamo and Blackwell, respectively. In the 2013 growing season switchgrass harvest was performed early in October. Following, alfalfa (var. Messe) was over-seeded with a no-till drill (seed dose $50 \mathrm{~kg} \mathrm{ha}^{-1}$ ) implementing a split-plot experimental design with three replicates, where switchgrass varieties, Alamo (AL) and Blackwell (BL), were considered as the main factor $(\mathrm{V})$, while the mixture stand (switchgrass + alfalfa, SA) or pure grass stand (pure switchgrass, PS) were the levels of the sub-factor treatment (T). The trial was carried out with no nitrogen fertilisation and under rainfed condition. In 2014 the stands were harvested four times, at June 26 (H1), July 31 (H2), September 8 (H3) and October 9 (H4). SA and PS were harvested at flowering stage of alfalfa. At each harvest time a sampling area of $1 \mathrm{~m}^{2}$ per sub-plot was sampled, cutting the herbage at fixed height of $3 \mathrm{~cm}$. The fresh weight of aboveground biomass was determined for all samples. In addition, in SA samples biomass was partitioned between alfalfa and switchgrass. For each stand and harvest time, biomass subsamples were placed in a forceddraft oven at a temperature of $60^{\circ} \mathrm{C}$ for the determination of the DM content. Therefore, the milled samples $(1 \mathrm{~mm})$ were analysed determining neutral detergent fibre (NDF), acid detergent fibre (ADF) and acid detergent lignin (ADL) by means of the Van Soest method (1991). Crude protein content (CP) was assessed with the Association of Official Analytical Chemists (AOAC) method (AOAC, 1990).

Yield and quality data were examined for homogeneity of variances and normality of residuals. The statistical analyses were performed using the R software (R Core Team, 2003). A split-plot analysis of variance (ANOVA) was used to highlight the difference between annual cumulated DM yield for the two varieties (AL and BL) in the two systems (SA and PS). In addition, a split-split-plot ANOVA was performed to analyse the differences between the DM yield and quality of the tested harvests, where $\mathrm{V}$ was considered as main factor, $\mathrm{T}$ as sub-factor and $\mathrm{H}$ was the sub-sub-factor.

\section{Results}

\section{Meteorological data}

During the period of observation (October 2013-October 2014) the total rainfall $(1327 \mathrm{~mm})$ was higher $(+30 \%)$ with respect to the longterm data (1971-2000; $1034 \mathrm{~mm})$. The October-to-February cumulative precipitation was higher $(+56 \%)$ than the corresponding long-term average. On the contrary, from March to October, rain amounted to 611 $\mathrm{mm}$, which did not substantially deviate from the correspondent longterm value $(575 \mathrm{~mm})$. However, the distribution of precipitation was substantially different, with a long dry period excluding March and July: both these months were rainier than the long-term average (101 vs 60 $\mathrm{mm}$ and 194 vs $25 \mathrm{~mm}$ in the two respective months). As defined by Bagnouls and Gaussen (1957), dry months, i.e., those where average temperature shown in a double scale passed precipitation, occurred only in June and August (Figure 1). Concerning air temperature, the average maximum temperature of the period was $21^{\circ} \mathrm{C}$ with monthly mean values higher than $27^{\circ} \mathrm{C}$ from June to September. The average minimum temperature of the period was $10^{\circ} \mathrm{C}$ with unusual high values, around $8^{\circ} \mathrm{C}$, in winter months.

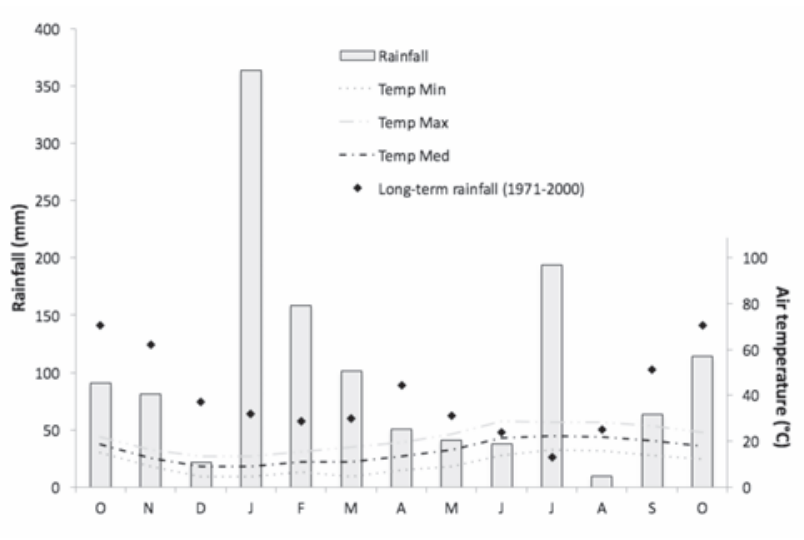

Figure 1. October 2013-October 2014 and long-term 1971-2000 monthly rainfall, minimum, average and maximum monthly air temperature in San Piero a Grado (Pisa, Italy). The graph is presented as a Bagnouls and Gaussen (1957) diagram, in order to identify dry months, i.e., when rainfall $(R)$ is equal to or lower than twice the monthly mean air temperature value $(T)(R \leq 2 T)$. 


\section{Aboveground biomass yield and quality}

In the first of observation, the cumulative biomass DM yield of each treatment ranged from 8.9 and $9.8 \mathrm{Mg} \mathrm{DM} \mathrm{ha}{ }^{-1}$ in the PS systems for Alamo and Blackwell, respectively. In addition, in the SA systems the yields increased with values about 10.0 and $11.8 \mathrm{Mg} \mathrm{DM} \mathrm{ha}^{-1}$ for Alamo and Blackwell.

Significant differences in the annual total DM yield were observed between SA and PS, but not between the switchgrass varieties (Table 1). The total yield of SA, after 4 cuts, was significantly higher by $19 \%$ than the PS. In fact, from the pure stand to the mixture, the annual total biomass increased from 9.3 to $11.1 \mathrm{Mg} \mathrm{DM} \mathrm{ha}^{-1}$. Switchgrass yield in SA decreased by about $20 \%$ with respect to PS (Figure $2 \mathrm{~A}$ ). The alfalfa productivity was affected by $\mathrm{V}$ and it represented the 29 and $36 \%$ of the total annual aboveground production in Alamo and Blackwell, respectively (Figure 2B). Biomass production was affected by $\mathrm{H}(\mathrm{P}<0.001)$, and the results of analysis of variance highlighted a significant interaction between harvest and treatment $(\mathrm{H} \times \mathrm{T})$ (Table 1$)$. $\mathrm{H} 1$ represented the main portion of annual DM yield, 76 and $52 \%$ for PS and SA stand respectively, and it was significantly higher than the other three harvests (Figure 3). Moreover, the DM yield in the H1 of PS was significantly higher than SA. In the H1, alfalfa was only the $2-3 \%$ of the total yield, but in the following three harvests the alfalfa yield was higher than that of switchgrass. In fact, in $\mathrm{H} 2, \mathrm{H} 3$ and $\mathrm{H} 4$, the yield of SA stands was significantly higher than PS (1.8 vs $0.7 \mathrm{Mg} \mathrm{DM} \mathrm{ha}^{-1}$ as average value of $\mathrm{H} 2, \mathrm{H} 3$ and $\mathrm{H} 4$ for SA and PS, respectively) (Figure 3). Alamo did not show biomass regrowth in the last period of the trials, i.e., after September 8, in both treatments.

Concerning biomass quality, the CP and NDF content of biomass were significantly influenced by variety, treatment, harvest and their interactions, excluding $\mathrm{T} \times \mathrm{V}$ for $\mathrm{CP}$ content (Table 1). CP content in SA stands was significantly higher in each harvest than the PS excepting H1. In fact in $\mathrm{H} 1$ the alfalfa fraction of the DM yield was the smallest, and the CP average content of SA was 45 compared to $38 \mathrm{~g} \mathrm{~kg}^{-1} \mathrm{DM}$ of PS (Figure 4A). At each harvest SA showed significantly lower NDF content than PS. Between varieties, NDF content decreased from SA to PS by $2,16,23 \%$ in the three succeeding harvests for Alamo, and by 2 , $26,44,28 \%$ in the four succeeding harvests for Blackwell (Figure 4B). The ADF content was not affected by the treatment; on the contrary it was significantly influenced by variety and harvest (Table 1). For Blackwell, at each harvest ADF was significantly higher in PS than SA, showing a decreasing trend in both treatments with almost constant difference about 5 ( $\left.\mathrm{g} \mathrm{kg}^{-1} \mathrm{DM}\right)$. For Alamo, the same differences

Table 1. Analysis of variance in total dry matter (DM) yield, switchgrass DM yield, crude protein content, neutral detergent fibre, acid detergent fibre, acid detergent lignin.

\begin{tabular}{|c|c|c|c|c|c|c|c|}
\hline Source of variation & df & Total DM yield & Switchgrass DM yield & $\mathrm{CP}$ & NDF & ADF & ADL \\
\hline Variety (V) & 1 & ns & ns & $* *$ & $* *$ & $*$ & ns \\
\hline Residual & 2 & - & - & - & - & - & - \\
\hline Treatment (T) & 1 & $* * * *$ & $* * * *$ & $* * *$ & $* * *$ & ns & $* *$ \\
\hline $\mathrm{T} \times \mathrm{V}$ & 1 & ns & ns & ns & $* * *$ & $* * *$ & $*$ \\
\hline Residual between & 4 & - & 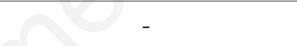 & - & - & - & - \\
\hline Harvest (H) & 3 & $* * *$ & $* * *$ & $* * *$ & $* * *$ & $* * *$ & $* * *$ \\
\hline $\mathrm{H} \times \mathrm{V}$ & 3 & $* * * *$ & $*$ & $* * *$ & $* * *$ & $* * *$ & $*$ \\
\hline $\mathrm{H} \times \mathrm{T}$ & 3 & $* * *$ & $* *$ & $* * *$ & $* * *$ & $* * *$ & $* * *$ \\
\hline $\mathrm{H} \times \mathrm{V} \times \mathrm{T}$ & 3 & ns & ns & $* * *$ & $* * *$ & $* * *$ & $* * *$ \\
\hline Residual within & 24 & - & - & - & - & - & - \\
\hline
\end{tabular}

df, degree of freedom; DM, dry matter; $\mathrm{CP}$, crude protein content; NDF, neutral detergent fibre; $\mathrm{ADF}$, acid detergent fibre; $\mathrm{ADL}$, acid detergent lignin; ns, not significant. ${ }^{* * * * P}<0.1 ; * * * \mathrm{P}<0.001 ; * * \mathrm{P}<0.01 ; * \mathrm{P}<0.05$.
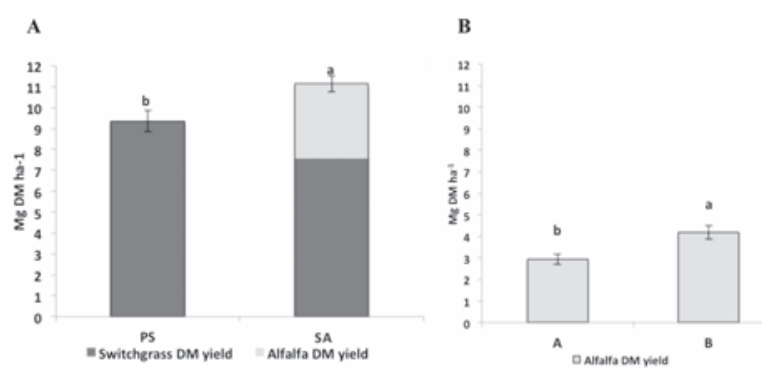

Figure 2. A) Total annual dry matter (DM) yield of mixture (SA) and pure (PS) switchgrass stand; B) total annual DM yield of alfalfa within the two switchgrass varieties (Alamo and Blackwell). Different letters indicate significant difference, Pvalue $<0.05$, for Tukey's honest significant difference test, between treatments (a) and varieties (b). Vertical bars represent standard errors.

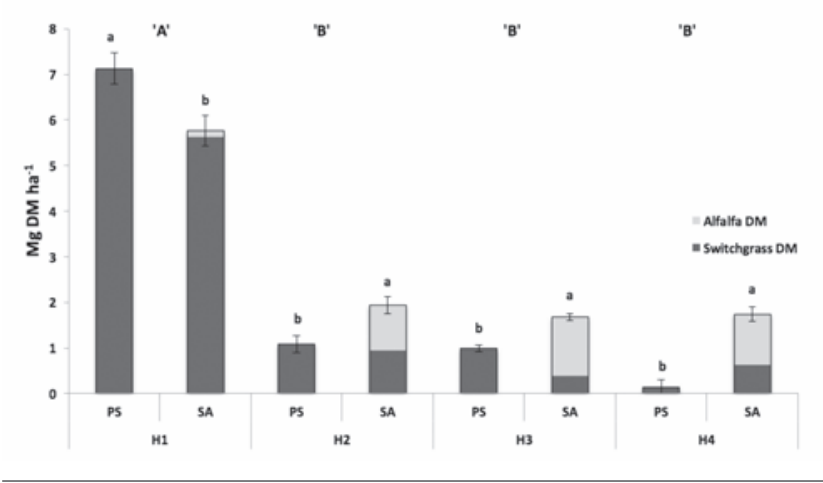

Figure 3. Total dry matter (DM) yield of pure switchgrass (PS) and switchgrass + alfalfa (SA) stands in each harvest $(\mathrm{H}) 1, \mathrm{H} 2$, $\mathrm{H} 3$ and H4. Different letters indicate significant difference, Pvalue $<\mathbf{0 . 0 5}$, for Tukey's honest significant difference test. Uppercase letters indicate differences between $\mathrm{H}$, lowercase letters indicate differences for the $\mathrm{H} \times \mathrm{T}$ (treatment) interaction. Vertical bars represent standard errors. 
between PS and SA were $\mathrm{H} 1$ and $\mathrm{H} 3$, while an opposite behaviour was observed in $\mathrm{H} 2$ (Figure 4C). The ADL content was affected by treatment and harvest (Table 1). In H1 ADL content of PS was significantly higher than SA (61 vs $49 \mathrm{~g} \mathrm{~kg}^{-1} \mathrm{DM}$ ), by contrast in $\mathrm{H} 2, \mathrm{H} 3$ and H4 ADL contents of SA were higher than PS (Figure 4D).

Linear correlation was observed between qualitative parameters and alfalfa share in the mixture biomass. Alfalfa share of dry matter yield was positively correlated with CP content (Figure 5), while it was negatively correlated with NDF content (Figure 6).

In addition, weighted average values of quality traits (calculated as sum of the values at each harvest weighted on the total yield) confirmed marked variation between the systems and slight differences between the varieties. Specifically, weighted average CP content of PS was 52 and $49 \mathrm{~g} \mathrm{~kg}^{-1} \mathrm{DM}$ in Alamo and Blackwell, respectively, while it increases in SA with $96 \mathrm{~g} \mathrm{~kg}^{-1} \mathrm{DM}$ in Alamo and $121 \mathrm{~g} \mathrm{~kg}^{-1} \mathrm{DM}$ in Blackwell. Weighted average NDF content varied from about 770 to 650 $\mathrm{g} \mathrm{kg}^{-1} \mathrm{DM}$ in PS and SA, respectively. A similar behaviour was observed for weighted average ADF content, ranging from 430 to $365 \mathrm{~g} \mathrm{~kg}^{-1} \mathrm{DM}$ in PS and SA, respectively. Finally, weighted average ADL content decreased from PS to SA in both varieties (56 vs $49 \mathrm{~g} \mathrm{~kg}^{-1} \mathrm{DM}$ ).

\section{Discussion}

The present study evaluated the suitability of alfalfa over-seeding in a mature switchgrass crop for forage production in a low-input (no fertilisation) rainfed system cultivated in the Mediterranean environment. Several authors described the potential of grass-legume mixture to improve forage quality (Gierus et al., 2012; Finn et al., 2013; Lüscher et al., 2014) and to enhance the seasonal distribution of biomass production compared to grass monocultures. Despite the fact that the first

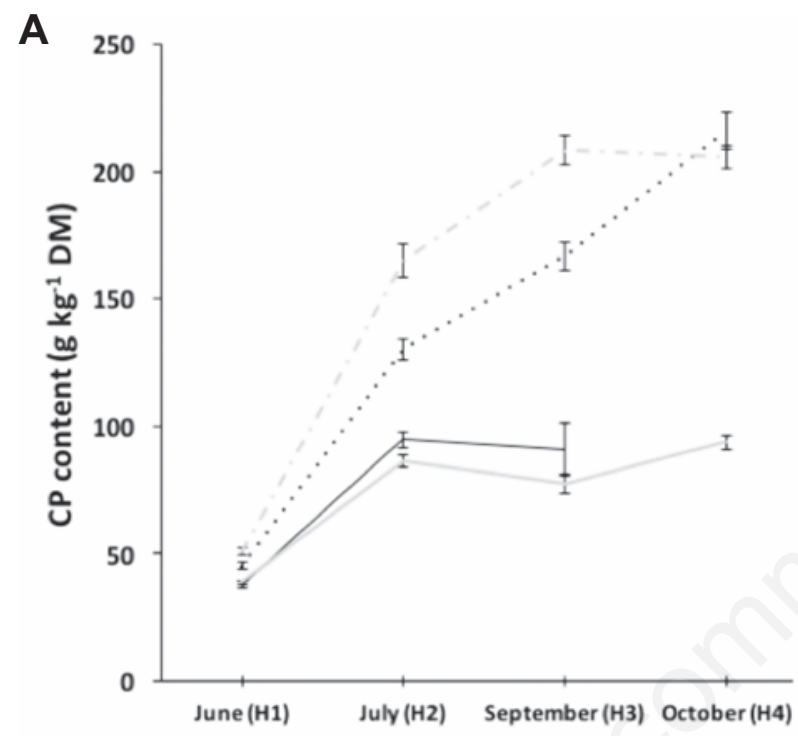

B
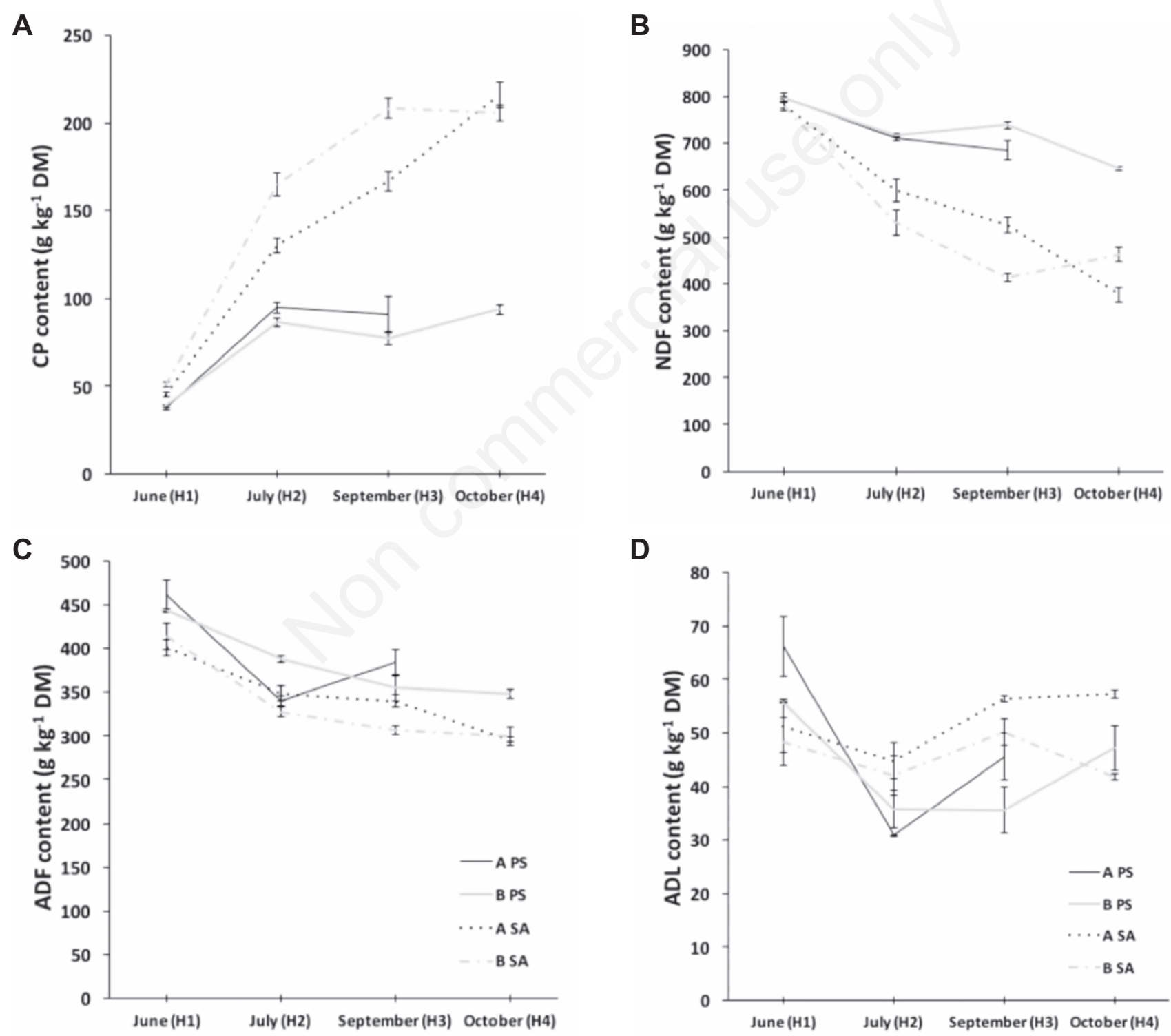

Figure 4. A) Crude protein (CP), B) neutral detergent fibre (NDF), C) acid detergent fibre (ADF), and D) acid detergent lignin (ADL) content of mixture (SA) and pure (PS) Alamo 'A' and Blackwell 'B' stands of each harvest (H1, H2, H3 and H4). Vertical bars represent standard errors. DM, dry matter. 
year of alfalfa is usually recognised as the least productive in the Mediterranean environment (Bonari et al., 1985), the first-year results allowed us to observe a positive effect of the intercropping in increasing the total annual yield of the stand by about $19 \%$ with respect to the pure switchgrass. However, the presence of alfalfa negatively affected switchgrass yield in the mixture. Indeed, the higher yield of the mixture manly depended on alfalfa productivity, since the grass growth was negatively affected by the legume competition. Wang et al. (2010) reported a similar increasing trend for legumes intercropped in switchgrass, even if they observed a positive influence of legumes on switchgrass yield. In our experiment, the pure switchgrass was harvested four times per season (according to the management system adopted for the mixture stand) and it produced $9.3 \mathrm{Mg} \mathrm{ha}^{-1}$ of DM. Alexopoulou et al. (2008) and Guretzky et al. (2010) for single and double harvest, respectively, showed similar results, suggesting a constant productivity of switchgrass in the first year of a multi-harvest management. The abundant rainfall occurred during summer period led to a satisfactory regrowth of herbage and from the second harvest onwards alfalfa yielded more than switchgrass. No significant differences were observed between the two switchgrass varieties both in the pure and in the mixture stand. These findings concur with those reported by Alexopoulou et al. (2008), who observed different yield potentials, among low-land and up-land varieties, just during the peak years and not in mature stands as in this case (switchgrass at the $6^{\text {th }}$ growth season). The intercropped alfalfa showed different behaviour between the two switchgrass varieties, probably due the different habit and growing cycle of Alamo, which negatively affected the alfalfa establishment compared with Blackwell. The plentiful yields of switchgrass did not comply with the nutritional values required for quality forage, having a low protein content particularly after boot stage (Rogers et al., 2012; Waramit et al.,

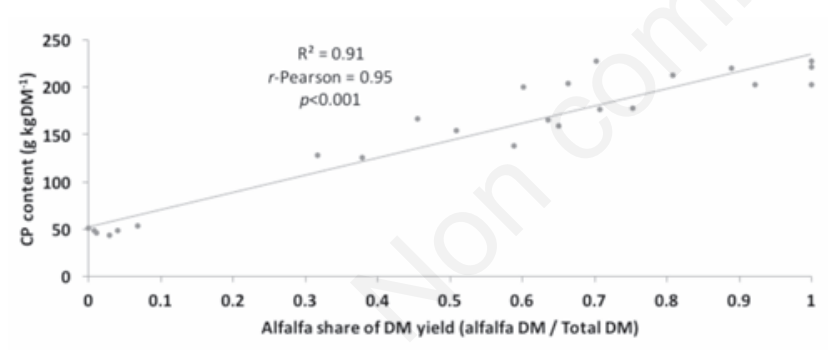

Figure 5. Crude protein (CP) content in switchgrass + alfalfa samples related of alfalfa share of dry matter (DM) yield.

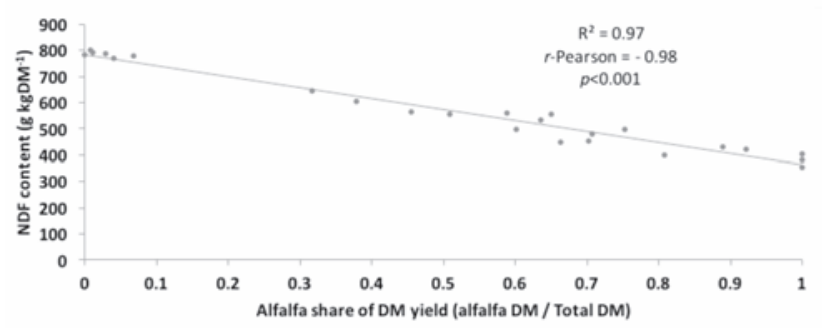

Figure 6. Neutral detergent fibre (NDF) content in switchgrass + alfalfa samples related of alfalfa share of dry matter (DM) yield.
2012; Mosali et al., 2013). In fact, Guretzky et al. (2010) and Rogers et al. (2014) recommended using switchgrass as forage only at vegetative stage, from spring to early summer, and they indicated, in a dual-purpose management, to use the herbage summer regrowth as feedstock biomass for cellulosic industry. Nevertheless, Burns and Fisher (2013) demonstrated the possibility of improving the performance of steers fed with switchgrass-based hay diet, by mixing the ration with alfalfa, as biological source of $\mathrm{CP}$.

Gierus et al. (2012), highlighted the key role of a legume in a binary grass-legume mixture stand, in order to improve the forage quality, complying with our results, that showed the extent to which intercropped alfalfa can enhance the forage biomass quality. In fact, the CP content was higher in the mixture than in the pure switchgrass, in both varieties. Conversely, the NDF in the mixture stands was higher in the pure switchgrass during all the growing season, regardless the harvest time.

This study showed that switchgrass monoculture might have critical limitations for forage use, due to the low quality of the fodder and to the drastic decrease of biomass yield when the crop is cultivated according to a multi-cut management system. Nevertheless, the intercropping with overseeded alfalfa enhanced the suitability of switchgrass as forage crop, by increasing the $\mathrm{CP}$ content while limiting the decrease of yields during the season.

Our results agree with Luscher et al. (2014) and they showed that grass-legume intercropping could increase the profitability of grassland-based livestock production. Moreover, the over-seeding of alfalfa is a low input practice that could allow growers to increase the profitability of senescing switchgrass stand, to restore the soil $\mathrm{N}$ content, while increasing the self-sufficiency in protein production of the farm.

\section{Conclusions}

The study showed the possibility to improve the suitability of switchgrass as fodder by intercropping with over-seeded alfalfa under rainfed Mediterranean conditions. During the first year of observation, we observed a higher yield and nutritional value in the mixed than pure biomass under a four-harvest management. In fact, the yield increased by about $20 \%$ from pure stand to grass-legume mixture, and in the latter the crude protein content was higher in each harvest. In our environment, where cool-season forage species are not able to produce pasture or fodder in summer dry period, warm-season grasses, such as switchgrass, can enhance quantity and distribution of forage. Moreover, the intercropping with legumes can improve the cropping system efficiency reducing the use of nitrogen. The progress of this study is essential to deepen the knowledge of the effects of intercropping of alfalfa and switchgrass in the long term. In addition, to evaluate the sustainability of this cropping system it is essential to extend the study also to environmental (e.g., use of nitrogen, GHG emissions) and economic aspects.

\section{References}

Alexopoulou E, Sharma N, Papatheohari Y, Christou M, Piscioneri I, Panoutsou C, Pignatelli V, 2008. Biomass yields for upland and lowland switchgrass varieties grown in the Mediterranean region. Biomass Bioenerg. 32:926-33.

Anglade J, Billen G, Garnier J, 2015. Relationships for estimating N 2 fixation in legumes: incidence for $\mathrm{N}$ balance of legume-based cropping systems in Europe. Ecosphere 6:1-24.

AOAC (Association of Official Analytical Chemists), 1990. Official 
methods of analysis, 15th ed. Association of Official Analytical Chemists, Inc., Arlington, VA, USA.

Ashworth AJ, Taylor AM, Reed DL, Allen FL, Keyser PD, Tyler DD, 2015. Environmental impact assessment of regional switchgrass feedstock production comparing nitrogen input scenarios and legumeintercropping systems. J. Clean. Prod. 87:227-34.

Bagnouls F, Gaussen H, 1957. Les climats biologiques et leur classification. Ann. Geogr. 355:193-220.

Bonari E, Masoni P, Mazzonici M, 1985. Analisi del ritmo di accrescimento dell'erba medica di diversa età e produzione di concentrati proteici fogliari. Ital. J. Agron. 19:147-54.

Burns JC, Fisher DS, 2013. Steer intake, digestion, and ingestive behavior of switchgrass and alfalfa hays. Crop. Sci. 53:716-23.

Burns JC, Fisher DS, Pond KR, 2011. Steer performance, intake, and digesta kinetics of switchgrass at three forage masses. Agron. J. 103:337-50.

Cheok CY, Salman HAK, Sulaiman R, 2014. Extraction and quantification of saponins: a review. Food. Res. Int. 59:16-40.

Durán Zuazo VH, Rodríguez Pleguezuelo CR, 2008. Soil-erosion and runoff prevention by plant covers. A review. Agron. Sustain. Dev. 28:65-86.

Finn JA, Kirwan L, Connolly J, Sebastià MT, Helgadottir A, Baadshaug $\mathrm{OH}$, Bélanger G, Black A, Brophy C, Collins RP, op J, Dalmannsdóttir S, Delgado I, Elgersma A, Fothergill M, FrankowLindberg BE, Ghesquiere A, Golinska B, Golinski P, Grieu P, Gustavsson AM, Höglind M, Huguenin-Elie 0, Jørgensen M, Kadziuliene Z, Kurki P, Llurba R, Lunnan T, Porqueddu C, Suter M, 2013. Ecosystem function enhanced by combining four functional types of plant species in intensively managed grassland mixtures: a 3-year continental-scale field experiment. J. Appl. Ecol. 50:365-75.

Gherbin P, De Franchi AS, Monteleone M, Rivelli AR, 2007. Adaptability and productivity of some warm-season pasture species in a Mediterranean environment. Grass Forage Sci. 62:78-86.

Gierus M, Kleen J, Loges R, Taube F, 2012. Forage legume species determine the nutritional quality of binary mixtures with perennial ryegrass in the first production year. Anim. Feed Sci. Technol. 172:150-61.

Glover JD, Reganold JP, Bell LW, Borevitz J, Brummer EC, Buckler ES, Cox CM, Cox TS, Crews TE, Culman SW, DeHaan LR, Eriksson D, Gill BS, Holland J, Hu F, Hulke BS, Ibrahim AMH, Jackson W, Jones SS, Murray SC, Paterson AH, Ploschuk E, Sacks EJ, Snapp S, Tao D, Van Tassel DL, Wade LJ, Wyse DL, Xu Y, 2010. Agriculture. Increased food and ecosystem security via perennial grains. Science 328:1638-9.

Glover JD, Reganold JP, Cox CM, 2012. Agriculture: plant perennials to save Africa's soils. Nature 489:359-61.

Guretzky JA, Biermacher JT, Cook BJ, Kering MK, Mosali J, 2010. Switchgrass for forage and bioenergy: harvest and nitrogen rate effects on biomass yields and nutrient composition. Plant Soil 339:69-81.

Havlik P, Valin H, Herrero M, Obersteiner M, Schmid E, Rufino MC, Mosnier A, Thornton PK, Bottcher H, Conant RT, Frank S, Fritz S, Fuss S, Kraxner F, Notenbaert A, 2014. Climate change mitigation through livestock system transitions. Proc. Natl. Acad. Sci. 111:3709-14.

Lee ST, Mitchell RB, Wang Z, Heiss C, Gardner DR, Azadi P, 2009. Isolation, characterization, and quantification of steroidal saponins in switchgrass (Panicum virgatum L.). J. Agric. Food Chem. 57:2599-604.

Lüscher A, Mueller-Harvey I, Soussana JF, Rees RM, Peyraud JL, 2014. Potential of legume-based grassland-livestock systems in Europe: a review. Grass Forage Sci. 69:206-28.

Monti A, Barbanti L, Zatta A, Zegada-Lizarazu W, 2012. The contribution of switchgrass in reducing GHG emissions. GCB Bioenergy 4:420-34.

Morgan JA, Follett RF, Allen LH, Del Grosso S, Derner JD, Dijkstra F, Franzluebbers A, Fry R, Paustian K, Schoeneberger MM, 2010. Carbon sequestration in agricultural lands of the United States. J. Soil Water Conserv. 65:6A-13A.

Mosali J, Biermacher JT, Cook B, Blanton J, 2013. Bioenergy for cattle and cars: a switchgrass production system that engages cattle producers. Agron. J. 105:960-6.

Nassi o Di Nasso N, Lasorella MV, Roncucci N, Bonari E, 2015. Soil texture and crop management affect switchgrass (Panicum virgatum L.) productivity in the Mediterranean. Ind. Crops Prod. 65:21-6.

Pulina G, Francesconi AHD, Mele M, Ronchi B, Stefanon B, Sturaro E, Trevisi E, 2011. Sfamare un mondo di nove miliardi di persone: le sfide per una zootecnia sostenibile. Ital. J. Agron. 6:39-44.

R Development Core Team, 2003. R: a language and environment for statistical computing. R Foundation for Statistical Computing, Vienna, Austria.

Rogers JK, Motal FJ, Mosali J, 2012. Yield, yield distribution, and forage quality of warm-season perennial grasses grown for pasture or biofuel in the southern Great Plains. ISRN Agron. 1-7.

Rogers JK, Nichols B, Biermacher JT, Mosali J, 2014. The value of native, warm-season perennial grasses grown for pasture or biofuel in the southern Great Plains, USA. Crop Pasture Sci. 65:550-5.

Soussana JF, Tallec T, Blanfort V, 2010. Mitigating the greenhouse gas balance of ruminant production systems through carbon sequestration in grasslands. Animal. 4:334-50.

Sulc RM, Franzluebbers AJ, 2014. Exploring integrated crop-livestock systems in different ecoregions of the United States. Eur. J. Agron. 57:21-30.

Vallebona C, Mantino A, Bonari E, 2016. Exploring the potential of perennial crops in reducing soil erosion: A GIS-based scenario analysis in southern Tuscany, Italy. Appl. Geogr. 66:119-31.

Van Soest PJ, Robertson JB, Lewis BA, 1991. Methods for dietary fiber, neutral detergent fibre, and nonstarch polysaccharides in relation to animal nutrition. J. Dairy. Sci. 74:3583-97.

Wang D, Lebauer DS, Dietze MC, 2010. A quantitative review comparing the yield of switchgrass in monocultures and mixtures in relation to climate and management factors. GCB Bioener. 2:16-25.

Waramit N, Moore KJ, Fales SL, 2012. Forage quality of native warmseason grasses in response to nitrogen fertilization and harvest date. Anim. Feed. Sci. Technol. 174:46-59.

Weightman RM, Cottrill BR, Wiltshire JJJ, Kindred DR, SylvesterBradley R, 2011. Opportunities for avoidance of land-use change through substitution of soya bean meal and cereals in European livestock diets with bioethanol coproducts. GCB Bioener. 3:158-70.

Wezel A, Casagrande M, Celette F, Vian JF, Ferrer A, Peigné J, 2014. Agroecological practices for sustainable agriculture. A review. Agron. Sustain. Dev. 34:1-20. 